\title{
KONEKTIVITAS PENGEMBANGAN PARIWISATA MELALUI KONSEP RUTE WISATA DI CIAYUMAJAKUNING \\ (Cirebon, Indramayu, Majalengka, dan Kuningan)
}

\author{
Mira Maharani ${ }^{1}$ \\ ${ }^{1}$ Sekolah Tinggi Pariwisata Trisakti, Jakarta, Indonesia, Email:mira \\ maharani@stptrisakti.ac.id
}

\begin{abstract}
ABSTRAK
Saat ini dengan adanya jalan bebas hambatan yang menghubungkan antara CikopoPalimanan-Kanci-Pejagan menjadi salah satu faktor yang berpengaruh besar bagi pariwisata di Ciayumajakuning ini berkembang pesat dikarenakan sekarang ini wilayah Ciayumajakuning menjadi salah satu pilihan tujuan wisata bagi wisatawan asal jakarta pada setiap akhir pekan selain Bandung. Pengembangan pariwisata di Ciayumajakuning diharapkan mampu berkontribusi terhadap peningkatan jumlah kunjungan wisatawan dan penyebaran wisatawan yang tidak hanya terpusat pada Kota Cirebon. Tujuan penelitian ini adalah mengembangkan pariwisata melalui rute wisata kawasan Ciayumajakuning. Pendekatan yang digunakan dalam penelitian ini adalah pendekatan kualitatif dan kuantitatif yang sama-sama dilakukan untuk ketersediaan data dan kondisi yang berbeda sesuai keperluan analisis. Kurang lebih terdapat 22 daya tarik wisata di Ciayumajakuning, namun hanya 13 daya tarik wisata yang terpilih menjadi prioritas daya tarik wisata yang masuk dalam rute wisata Ciayumajakuning. Dalam pemilihan daya tarik wisata strategis ini menggunakan konsep 5A. Setelah terpilih daya tarik wisata strategis maka baru akan dilakukan penyusunan rute wisata, Rute Wisata di Ciayumajakuning dibagi menjadi 3, yaitu Rute Wisata Kota; Rute Wisata Barat; dan Rute Wisata Timur, setelah tersusunnya rute wisata maka diperlukan juga analisis mengenai infrastruktur pendukung yang dibutuhkan pada daya tarik wisata yang termasuk dalam rute wisata agar daya tarik wisata semakin berkembang menjadi baik dan semakin siap dalam menerima wisatawan datang.
\end{abstract}

Kata Kunci: Pariwisata; Rute wisata; Ciayumajakuning; Pengembangan; Paket Wisata

\section{TOURISM DEVELOPMENT CONNECTIVITY THROUGH THE CONCEPT OF TOURIST ROUTES IN CIAYUMAJAKUNING (Cirebon, Indramayu, Majalengka, dan Kuningan)}

\begin{abstract}
At present, the existence of a highway that connects Cikopo-Palimanan-Kanci-Pejagan has become one of the factors that have a big influence on tourism in CIAYUMAJAKUNING, this is growing rapidly because now the CIAYUMAJAKUNING area is one of the preferred tourist destinations for tourists from Jakarta every weekend. apart from Bandung. It is hoped that tourism development in CIAYUMAJAKUNING will be able to contribute to the increase in the number of tourist visits and the spread of tourists that are not only focused on the city of
\end{abstract}


Cirebon. The purpose of this research is to develop tourism through the tourist route of the Ciayumajakuning area. The approach used in this study is a qualitative and quantitative approach which are both carried out for the availability of data and different conditions according to the needs of the analysis. There are approximately 22 tourist attractions in Ciayumajakuning, but only 13 tourist attractions have been selected as priority tourist attractions that are included in the Ciayumajakuning tourist route. In selecting this strategic tourist attraction using the 5A concept. After selecting a strategic tourist attraction, a new tourist route will be arranged. The tourist route in Ciayumajakuning is divided into 3, namely the City Tour Route; Western Tourist Routes; and East Tourism Route, after the formulation of the tourist route, it is also necessary to analyze the supporting infrastructure needed for the tourist attractions included in the tourist route so that the tourist attraction will develop better and be more ready to receive tourists coming.

Keywords : Tourism; Tourist Route; Ciayumajakuning; Development; Tour Packages

\section{Copyright (02021. UHN IGB Sugriwa Denpasar. All Right Reserved}

\section{PENDAHULUAN}

Ciayumajakuning merupakan kawasan pariwisata andalan yang antisipatif terhadap perkembangan pembangunan wilayah perbatasan yang meliputi Kabupaten Cirebon, Kota Cirebon, Kabupaten Indramayu, Kabupaten Majalengka, dan Kabupaten Kuningan. Pada Peraturan Daerah No 22 Tahun 2010 Tentang Rencana Tata Ruang Provinsi Jawa Barat Tahun 2009-2029 terdapat banyak perencanaan mengenai pembangun infrastruktur untuk perjalanan darat, laut dan udara di wilayah Ciayumajakuning ini sehingga pada masa mendatang akan semakin dimudahkan untuk mendatangi wilayah Ciayumajakuning.

Saat ini dengan mulai beroperasinya jalan bebas hambatan atau biasa disebut jalan tol yang menghubungkan antara CikampekCikopo-Palimanan-Kanci-Pejagan pada akhir tahun 2015 ini menjadikan sektor pariwisata di wilayah Ciayumajakuning ini berkembang pesat karena Ciayumajakuning saat ini diperkirakan menjadi salah satu pilihan tujuan wisata bagi wisatawan pada akhir pekan

Potensi wisata di Ciayumajakuning cukup berpotensi terutama pada wisata alamnya. Salah satu kendala pengembangan pariwisata di Ciayumajakuning adalah jauhnya antara satu objek dengan objek lainnya, selain itu pada umumnya wisatawan hanya berkumpul pada satu titik objek wisata saja, sehingga tidak tersebar kepada objekobjek lain yang mungkin masih belum banyak wisatawan tahu. Hal lainnya juga kondisi sarana prasarana penunjang objek wisata masih ada yang belum memadai, serta masih banyaknya informasi mengenai objek wisata yang memiliki potensi namun tidak terpublikasikan secara meluas.

Penelitian tentang konsep rute wisata sangat penting dilakukan sebagai konektivitas antara objek wisata satu dengan lainnya dalam pengembangan pariwisata suatu wilayah. Studi ini merupakan pengantar awal pengembangan pariwisata di Ciayumajakuning berdasarkan konsep rute wisata sehingga kedepannya pembangunan dan pengembangan sektor kepariwisataan dapat tumbuh dan berkembang secara lebih terhubung.

\section{LITERATUR REVIEW}

Pembentukan strategi concentration melalui gateway pariwisata, area staging dan clustering atraksi menjadi hal penting dalam merencanakan kawasan pariwisata. Sedangkan di sisi lain strategi concentration sering dipandang berlawanan dengan dari strategi dispersal (Meyer, 2004). Kedua strategi tersebut memiliki perannya masing-masing dan memiliki keterkaitan satu sama lain dalam pembangunan pariwisata. 
Konsep gateway umumnya mengacu kepada entry point atau titik masuknya wisatawan dari suatu negara atau wilayah dalam rute transportasi, seperti bandara, pelabuhan dan jalan raya, dimana wisatawan melewatinya ketika memasuki destinasi wisata. Terkait dengan gateway terdapat konsep area staging yang merupakan area terdekat dari gateway yang biasanya terdapat fasilitas yang dibutuhkan oleh wisatawan saat pertama kali datang, jika area staging tersebut bukan merupakan destinasi terakhir. Sedangakan jika area staging merupakan destinasi terakhir, umumnya area berisikan segala fasilitas dalam memenuhi kebutuhan wisatwan seperti akomodasi, pusat perbelanjaan, pelayanan pariwisata dan lainnya. Terkadang gateway dengan skala nasional maupun regional terletak di atau dekat kota- kota besar, dan kota besar tersebut menjadi area staging.

Clustering daya tarik wisata menurut Inskeep dalam Meyer (2004) merupakan prinsip perencanaan yang penting dalam rangka untuk menarik lebih banyak wisatawan ke suatu daerah dan mendorong mereka untuk tinggal lebih lama serta memudahkan dalam mengorganisir tur dan penyediaan infrastruktur, keuntungan clustering meliputi:

1. Kesempatan yang sangat baik untuk merencanakan pembangunan yang terintegrasi dan penerapan pengembangan, rancangan dan kontrol lingkungan.

2. Efisiensi dalam penyediaan akses transportasi dan infrastruktur;

3. Kenyamanan bagi para wisatawan karena dekatnya fasilitas dan pelayanan pariwisata;

4. Kemampuan dalam pengembangan terkonsentrasi dalam mendukung fasilitas dan pelayanan secara umum dan khusus; dan

5. Penangkalan untuk setiap dampak negatif terhadap lingkungan dan sosial budaya di daerah tertentu.

Meyer (2004) menyatakan bahwa pentingnya atraksi pelengkap untuk menyebarkan wisatawan yang terkonsentrasi dengan adanya tourism hub atau mini-hub. Dengan adanya mini-hub dan penciptaan daya tarik wisata baru tidak hanya diversifikasikan kedalam produk dan jasa pariwisata, tetapi hal tersebut memungkinkan untuk wisatawan mengeluarkan uangnya lebih banyak dan meningkatkan length of stay. Dengan demikian kawasan marjinal berkesempatan untuk mengembangan dan menawarkan daya tariknya sehingga dapat terasa dampak positif dari ekonomi pariwisata.

Mini-hub menuju rute pariwisata memiliki tingkatan sangat ideal untuk dijadikan pusat informasi pariwisata, yang dapat membantu memenuhi harapan wisatawan dan meningkatkan apresiasi terhadap lingkungan di sekitarnya dengan memberikan infomasi yang mencakup tentang komunikasi lokal dan gaya hidup penduduk asli setempat, serta dapat berfungsi sebagai mediasi antara fasilitas tradisional dan bisnis pariwisata yang sudah berkembang (Meyer, 2004).

Wisatawan memiliki karakteristik berbeda-beda sesuai dengan motivasinya berlibur, sesuai dengan pernyataan Flognfeldt (2005) dalam perencanaan pariwisata terkait rute haruslah memperhatikan beberapa tipe segmentasi seperti daerah asal wisatawan, motivasi perjalanan, moda transportasi yang digunakan, akomodasi dan variabelvariabel sosial demogafi. Klasifikasikan beberapa skema rute berdasarkan segmentasi wisatawan pertama kali diperkenalkan oleh Campbell dalam Flognfeldt (1999) dengan membaginya kedalam 5 skema.

1. Day trips, perjalanan wisata dimulai dan berakhir di daerah asal wisatawan dihari yang sama dengan waktu yang relatif singkat sehingga wisatawan tipikal ini disebut excursions.

2. Resort Trips, perjalanan dengan motivasi utamanya untuk menginap di kawasan destinasi khusus menyediakan akomodasi. Semakin lama wisatawan tinggal di tempat ini maka semakin banyak uang yang dikeluarkan oleh wisatawan, terkait hal ini peran 
pemasaran dibutuhkan sebagai cara untuk menarik dan meningkatkan lama tinggal wisatawan.

3. Base Holiday Trips, pejalanan menuju area dimana terdapat fasilitas akomodasi yang bisa digunakan wisatwan untuk menetap dan menginap kurang lebih 3 malam. Area tersebut juga menjadi titik awal wisatawan melakukan trips kebebrapa daya tarik terdekat. Wisatwan sendiri terbagi menjadi dua jenis berdasarkan tempat mereka menginap yaitu mereka yang tinggal dan menginap di base holiday trips dan mereka yang menginap di luar itu.

4. Roundtrips, terdapat dua klasifikasi terkait roundtrips yaitu tour operated roundtrips dan roundtrips by private cars or recreation vehicles. Tour operated roundtrips dapat dilihat dari wisatawan dapat mengunjungi tempattempat baru setiap harinya dengan dijemput oleh seorang intruktur dan biasanya menggunakan moda transportasi kereta dan bus sesuai jadwal yang telah ditentukan oleh operator tur. Wisatawan grup ini biasanya tinggal dalam waktu relatif singkat. Sedangkan wisawatan yang melakukan roundtrips by private cars or recreation vehicles pada dasarnya merencanakan jadwal liburannya sendiri dengan menggunakan moda transportasi pribadi dan biasanya tinggal dalam waktu yang cukup panjang.

5. Passing Through, skema ini dijelaskan bahwa wisatawan melakukan perjalanan menuju destinasi utama dengan mengunjungi beberapa daya tarik sebelum dan sesudah destinasi utama dan meninggalkan kawasan destinasi melalui gateway/ pintu keluar yang berbeda dari pintu masuk.

Penelitian dan pengembang pariwisata mengatakan bahwa ada beberapa elemen kunci yang penting bagi keberhasilan tujuan wisata. Ini secara tradisional disebut sebagai 5A-termasuk; Accessibilty,
Accomodation, Atraction, Activity, dan Amenities.

1. Accessibilty: Agar tujuan bisa berjalan layak bagi wisatawan, pasti ada beberapa cara untuk sampai ke negara, kawasan, dan berbagai atraksi. Ini tidak berarti harus ada kelas pertama atau transportasi massal yang tersedia untuk semua hal, tapi itu berarti 9akses harus dimungkinkan. Akses berhubungan dengan transportasi tapi hanya bisa merujuk pada jalur jalan setapak atau jalur bersepeda.

2. Accomodation: Jika wisatawan lebih dari sekedar pengunjung satu hari, mereka harus tinggal di tempat lain. Penting bagi tujuan wisata untuk menawarkan beragam fasilitas akomodasi, dalam hal rentang harga yang berbeda. Terkadang, akomodasi tersebut hampir menjadi bagian dari daya tarik tujuan, terutama jika itu menghadap pemandangan spektakuler atau tengara.

3. Atraction: Turis jarang melakukan perjalanan ke tempat tujuan hanya untuk tinggal di tempat akomodasi tertentu. Mereka biasanya melakukan perjalanan untuk melihat tujuan apa yang ditawarkan oleh mereka dalam hal apa yang dapat mereka lihat, lakukan dan alami. Fitur yang menarik seseorang ke tujuan tertentu dikenal sebagai atraksi. atraksi dapat menjadi keajaiban alam, atraksi buatan manusia, acara khusus, situs budaya atau sejarah, seni dan kerajinan, olahraga, musik atau tarian, flora dan fauna yang tidak biasa atau unik, kehidupan malam dan lainnya Atraksinya banyak dan beragam. Oleh karena itu, semakin luas berbagai objek wisata yang mungkin menarik bagi sejumlah besar wisatawan.

4. Activity: Wisatawan dapat menikmati kegiatan tertentu sementara di tempat tujuan mereka. Kegiatan ini meliputi; belanja, makan di luar, menggunakan fasilitas olahraga dan melakukan perjalanan rekreasi di luar ruangan (antara lain kegiatan). 
5. Amenities: Fasilitas tujuan meliputi penyediaan listrik dan air, fasilitas sanitasi, air minum yang aman, jalan, polisi dan layanan darurat, fasilitas pos dan komunikasi, media, dan lain-lain. Krusial, struktur ini memastikan bahwa para wisatawan tetap aman dan sehat selama berada di tempat tujuan. Wisatawan harus memiliki akses ke fasilitas dasar untuk merasa nyaman dan aman..

\section{METODE}

Terkait informasi yang didapat melaui interview dan observasi langsung, studi ini menerapkan pendekatan kualitatif dalam upaya analisisnya. Pendekatan kualitatif dilakukan untuk analisis berdasarkan data kualitatif, terutama untuk menganalisis kondisi daya tarik wisata dan hubungannya satu sama lain, serta untuk menganalisis berbagai elemen analisis dalam perumusan rencana rute wisata untuk Ciayumajakuning.

Selain itu, studi ini juga menggunakan pendekatan kuantitatif yang mendukung analisis. kuantitatif Menurut Sugiyono (2015), merupakan metode penelitian yang berlandaskan pada filsafat positivisme, digunakan untuk meneliti pada populasi atau sampel tertentu, teknik pengambilan sampel pada umumnya dilakukan secara random, pengumpulan data menggunakan instrumen penelitian, analisis data bersifat kuantitatif/statistik.

Pendekatan kuantitatif yang digunakan dalam studi ini adalah pendekatan yang banyak berfokus pada analisis data numerik. Pendekatan kuantitatif dilakukan untuk analisis data yang bersifat kuantitatif dalam elemen analisis untuk perumusan rencana rute wisata Ciayumajakuning.

Metode analisis untuk penelitian ini adalah melalui analisis deskriptif, analisis kebijakan, analisis penentuan daya tarik menggunakan indikator, dan analisis spasial seperti berikut ini.

1. Analisis deskriptif dilakukan terhadap daya tarik wisata, fasilitas umum, fasilitas pendukung, dan aksesibilitas di setiap ruas jalan menuju daya tarik wisata di wilayah studi.

2. Analisis kebijakan digunakan sebagai landasan dalam rencana pengembangan rute wisata Ciayumajakuning. Pengembangan rute wisata pun diupayakan sesuai dengan kebijakan yang ada.

3. Analisis penentuan daya tarik wisata strategis melalui indikator. Indikator dirumuskan berdasarkan teori yang ada, lalu dimodifikasi agar sesuai dengan analisis yang akan dilakukan. Beberapa daya tarik wisata yang ada di dalam wilayah studi akan dinilai berdasarkan indikator untuk dicari daya tarik wisata strategis yang sesuai dengan isu yang ada.

4. Analisis spasial dilakukan untuk melihat letak berbagai daya tarik yang ada di Ciayumajakuning serta dalam penentuan rute wisata yang sesuai. Analisis ini berfokus pada penyusunan rute wisata. Penyusunan rute wisata ini melibatkan identifikasi terhadap tiga faktor, yakni daya tarik wisata strategis, faktor pendukung daya tarik wisata, dan identifikasi hubungan daya tarik wisata dengan faktor pendukung.

Pada penelitian ini menggunakan teknik pengumpulan data seperti berikut:

1. Data Primer

Data primer merupakan sumber data yang diperoleh langsung di lapangan yaitu berupa observasi, wawancara, dan dokumentasi.

a. Observasi

Pengumpulan data dengan observasi langsung atau dengan pengamatan langsung merupakan teknik pengumpulan data dengan menggunakan mata dalam arti secara ilmiah tanpa dibantu alat strandart lain untuk keperluan tersebut. Dalam penelitian ini dilakukan pengamatan secara langsung terhadap wisatawan di Ciayumajakuning, sehingga data yang diperoleh lebih rinci dan nyata dengan melihat secara langsung fisik, gejalan atau fenomena objek penelitian. 
b. Wawancara

Teknik wawancara yang digunakan dalam penelitian ini adalah wawancara tak terstruktur dengan responden terdiri ataas mereka yang dipilih karena memiliki pengetahan dan mendalami situasi sehingga lebih mengetahui informasi yang diperlukan peneliti. Wawancara dilakukan dengan beberapa pihak yaitu:

1) Bappeda Kota Cirebon untuk mengetahui bagaimana pengembangan pariwisata di cirebon.

2) Pemandu wisata/pengelola wisata yang ada disetiap destinasi.

c. Dokumentasi

Studi dokumen merupakan pelengkap dari penggunaan metode observasi dan wawancara dalam penelitian kualitatif.

2. Data Sekunder

Data sekunder merupakan sumber data yang dipreoleh secara tidak langsung yaitu berupa dokumentasi dengan memanfaatkan data dari buku, jurnal, skripsi, tesis, disertasi, surat kabar, internet dan bahan lainnya yang relevan pada penelitian ini.

\section{HASIL DAN PEMBAHASAN}

Ciayumajakuning mempunyai berbagai sumberdaya wisata baik alam dan maupun buatan, yang sangat berpotensi menarik kunjungan wisatawan dalam jumlah besar. Dalam banyak hal, wilayah Ciayumajakuning mempunyai kenggulan kompetitif dalam hal pariwisata, dari segi lokasi, dapat menjadi destinasi wisata wilayah Jawa Barat bagian timur dan wilayah Jawa Tengah bagian barat dan pengembangan Bandara Internasional Jawa Barat menjadi hub transportasi regional, nasional dan internasional. Pariwisata unggulan di Ciayumajakuning saat ini adalah wisata ziarah/sejarah dan wisata religi, dengan adanya kesepuhan Cirebon dan didukung oleh berbagai daya tarik lainnya di sekitar Ciayumajakuning.

Daya tarik wisata di Ciayumajakuning sekarang ini sedang berkembang karena dipengaruhi oleh banyak faktor, antara lain dengan beroperasinya Jalan Tol Cipali yang memudahkan pergerakan wisatawan dari DKI Jakarta menuju Kota Cirebon dan sekitarnya. Dalam penelitian ini dilakukan suvei terhadap 21 daya tarik wisata dari beberapa wilayah di Ciayumajakuning. Berikut daya tarik wisata yang dikunjungi survei untuk riset ini.

Langkah-langkah pengembangan yang dilakukan adalah mengidentifikasi daya tarik wisata yang potensial di Ciayumajakuning yang mampu mendukung kegiatan wisata, mengetahui kondisi Ciayumajakuning terkait daya tarik, infrastruktur, dan kapasitasnya untuk mendukung pengembangan pariwisata; menciptakan konsep pengembangan pariwisata di Ciayumajakuning yang dapat mendukung kegiatan pariwisata di Sekitar Ciayumajakuning serta merumuskan strategi yang dapat diterapkan yang dapat mendukung konsep pengembangan tersebut.

Dalam menentukan daya tarik wisata strategis di wilayah ini, maka dilakukan suatu analisis terhadap seluruh daya tarik wisata menggunakan indikator-indikator penilaian. Dibawah ini merupakan kriteria penilaian dari 5 indikator yang masingmasing menjelaskan mengenai skala $1-5$ yang dijadikan sebagai nilai yang digunakan dalam scoring penentuan daya tarik wisata prioritas.

Berikut ini penjabaran rinci indikator penilaian dalam menentukan daya tarik wisata strategis di Ciayumajakuning:

1. Accomodation

Ini mengacu pada tempat dimana para wisatawan akan menginap. Penting bagi tujuan wisata untuk menawarkan beragam fasilitas akomodasi, dalam hal rentang harga yang berbeda.

2. Accesibility

Aksesibilitas mengacu pada sarana dimana turis dapat datang atau pergi dari tempat tujuan tertentu. Aksesibilitas dilakukan dengan berbagai sarana transportasi seperti maskapai penerbangan, kereta api, mobil dan feri.

3. Activity

Wisatawan dapat menikmati kegiatan tertentu sementara di tempat tujuan 
mereka. Kegiatan ini meliputi; belanja, makan di luar, menggunakan fasilitas olahraga dan melakukan perjalanan rekreasi di luar ruangan (antara lain kegiatan).

\section{Amenities}

Fasilitas yang bisa diikutsertakan dalam wisata kota seperti restoran, bar dan pusat perbelanjaan. Fasilitas juga meliputi penyediaan listrik dan air, fasilitas sanitasi, air minum yang aman, jalan, polisi dan layanan darurat, fasilitas pos dan komunikasi, media, dan lain-lain. Attraction

Atraksi merupakan faktor penarik utama wisatawan ke tujuan. Atraksi bisa dikategorikan menjadi tempat wisata heritage dan atraksi komersial. Atraksi warisan terutama termasuk situs yang membawa kenangan dan pengalaman dengan tambahan tempat pertunjukan keajaiban alam dunia

Dalam penelitian ini dilakukan survey pada 22 daya tarik wisata yang tersebar di wilayah Kota Cirebon, Kabupaten Cirebon, Kabupaten Majalengka, dan Kuningan. Sebagian besar daya tarik tersebut merupakan daya tarik wisata alam berupa tebing-tebing, kolam pemandian dan pegunungan, selain itu juga banyak terdapat tempat-tempat bersejarah seperti keraton, situs purbakala dan gedung perjanjian linggarjati.

Melalui analisis dari Lima indikator yang terdiri dari Attraction, Activity, Accesibility, Accomodation dan Amenities, dimana masing-masing hasil indikator ini kemudian dijumlahkan untuk memperoleh nilai total dari setiap daya tarik wisata, maka diketahui bahwa terdapat 14 daya tarik wisata strategis di wilayah Ciayumajakuning yang dapat mendukung kegiatan pariwisata sebagai daya tarik wisata prioritas Ciayumajakuning.

Daya tarik wisata yang telah dilakukan survei terdapat dua puluh dua daya tarik wisata sedangkan untuk menentukan daya tarik wisata strategis dilihat dari total skor yang berjumlah minimal 15, maka terdapat tiga belas daya tarik wisata yang terpilih menjadi daya tarik wisata strategis, pada wilayah Cirebon dan Kabupaten Cirebon yakni: Keraton Kasepuhan (19), Keraton Kacirebonan (21), Taman Sari Goa Sunyaragi (22), Cirebon Waterland (22) dan Batik Trusmi (19).

Berikutnya daya tarik wisata yang terpilih pada wilayah Kuningan yakni: Batu Lawang (15), Telaga Nilam (17), Pemandian Cibulan (19), Curug Putri Paluntungan (18), Gedung Perundingan Linggarjati (18), Situs Purbakala Cipari (15), dan Tenjo Laut Paluntungan (17). Sedangkan pada wilayah Majalengka hanya ada 1 daya tarik wisata yang terpilih yaitu Batu Luhur (19).

Pada penelitian ini, penulis melakukan plotting lokasi daya tarik dan objek wisata di Ciayumajakuning. Plotting dilakukan berdasarkan data Google Maps, dan diverifikasi posisinya melalui survei primer. Dari hasil plotting ini, dilakukan pengelompokkan cluster daya tarik dan objek wisata yang berdekatan dan mungkin dijadikan rute wisata berdasarkan teori rute wisata yang telah dipaparkan pada bagian sebelumnya.

Dari hasil plotting ini, daya tarik wisata Ciayumajakuning dikelompokkan menjadi 3 cluster, yakni Kelompok Kota, Kelompok Barat, dan Kelompok Timur berdasarkan teori dan konsep rute wisata. Hasil pengelompokkan daya tarik dan objek wisata dapat dilihat pada Gambar 1 di bawah ini.

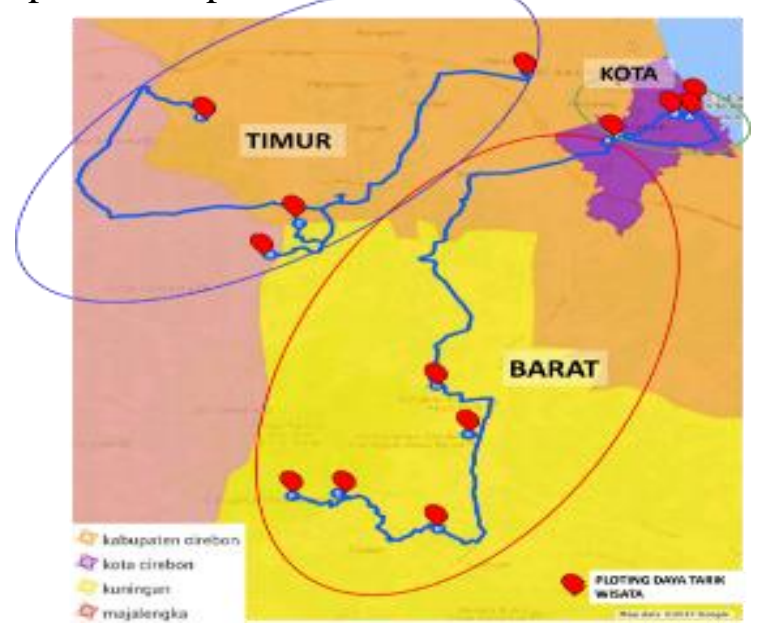

Gambar 1. Plotting Daya Tarik Wisata pada Rute Wisata Ciayumajakuning 
Dalam gambar dijelaskan bahwa untuk lingkaran yang bertuliskan kota merupakan rute wisata di kota cirebon, sedangkan untuk lingkaran yang bertuliskan barat merupakan rute wisata di Kuningan atau sebelah barat dari kota Cirebon dan lingkaran yang bertuliskan timur merupakan rute wisata yang terpencar berada di sebelah timur Cirebon. Setelah dilakukan survei, peneliti melihat adanya kemungkinan munculnya banyak daya tarik wisata baru yang dikemas menjadi objek wisata yang menarik di Ciayumajakuning karena potensi pariwisatanya yang tinggi.

Saat ini, terlihat pola adanya daya tarik wisata dan objek wisata di Ciayumajakuning yang memanfaatkan adanya Tol Cipali, Gunung Ciremai, dan bekas-bekas tempat tambang batu, serta pemandangan dan potensi alam dan budaya yang ada di sekitarnya. Namun, tidak menutup kemungkinan adanya rute wisata baru yang melibatkan wilayah ini apabila terdapat daya tarik wisata yang strategis ataupun potensial, terutama apbila rute wisata tersebut bekerjasama dengan daya tarik wisata yang ada di Kota Cirebon.

Rute wisata ini terdiri dari tiga alternatif rute yang dibagi berdasarkan kedekatan jarak antar DTW. Rute ini terbagi atas Rute Kota, Rute Barat dan Rute Timur yang dimana rute tersebut disesuaikan dari dasar rute, waktu kunjungan rute dan skema rute. Rute-rute wisata ini akan dijelaskan secara lengkap sebagai berikut.

Rute wisata kota merupakan rute wisata yang dibuat berdasarkan data sekunder yang diverifikasi melalui survei langsung mengenai destinasi wisata yang ada di sekitaran wilayah Kota Cirebon. Setelah dibuat rute, dilakukan survei primer terhadap rute ini. Daya tarik wisata yang menjadi nodes di Rute Wisata Kota ini diantaranya adalah Keraton Kasepuhan, Keraton Kacirebonan, Taman Sari Gua Suyaragi, Cirebon Waterland Ade Irma Suryani, dan Batik Trusmi. Visualisasi Rute Wisata Kota dapat dilihat pada Gambar 2 di bawah ini:

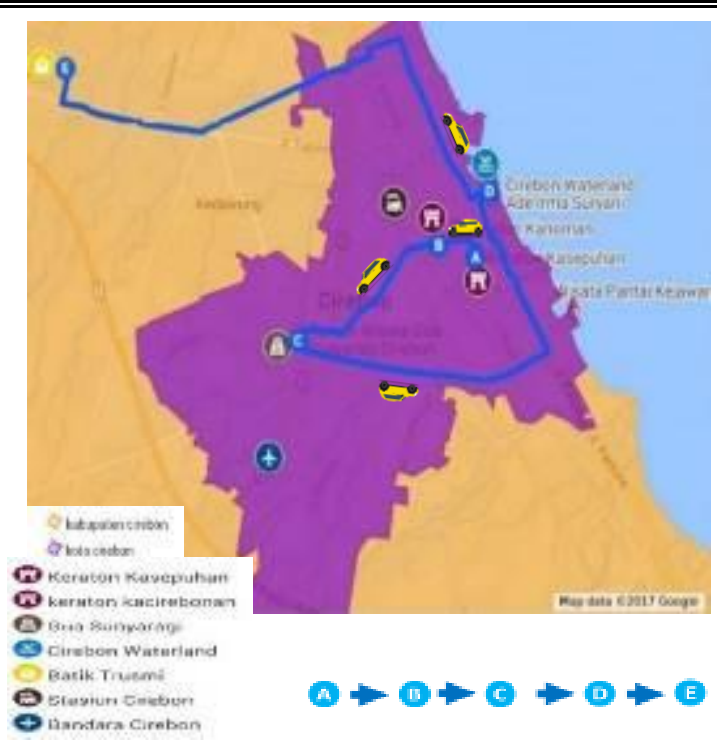

Gambar 2. Rute Wisata Cirebon

Dari hasil survei, diketahui karena berada di kawasan kota besar sehingga mengenai akses, transportasi umum, dan fasilitas menginap di Rute Wisata Kota ini sudah cukup baik. Pada jalan arteri sekitaran Cirebon, ketersediaan fasilitas penunjang pariwisata seperti penginapan, rumah makan, mini market, toko cinderamata atau oleholeh, dan lain sebagainya sangat memadai. Banyak terdapat penginapan mulai dari hotel kelas melati hingga hotel berbintang yang ditemukan pada ruas Jalan Cirebon menuju daya tarik wisata di Rute Wisata Kota, serta rumah makan dan toko oleh-oleh dengan jumlah yang cukup banyak. Secara keseluruhan, daya tarik yang ditawarkan dalam Rute Wisata Kota merupakan daya tarik wisata sejarah yang kemudian dikembangkan oleh kelompok atau komunitas. Daya tarik yang dimaksud antara lain berupa Keraton, dan Taman Sari Gua Sunyaragi. Daya tarik pada kawasan ini antara daya tarik wisata berjarak cukup dekat, yaitu sekitar $1-5 \mathrm{~km}$, karena masih terletak pada daerah yang sama yaitu Kota Cirebon.

Rute Wisata Barat terdiri dari 5 daya tarik wisata, secara berurutan adalah Gedung Perundingan Linggarjati-Pemandian CibulanSitus Purbakala Cipari-Curug Putri Paluntungan-Tenjo Laut. Rute Wisata Barat dibuat berdasarkan data sekunder yang kemudian dikonfirmasikan lagi pada survei 
primer. Dapat dilihat pada gambaran peta di Gambar dibawah ini:

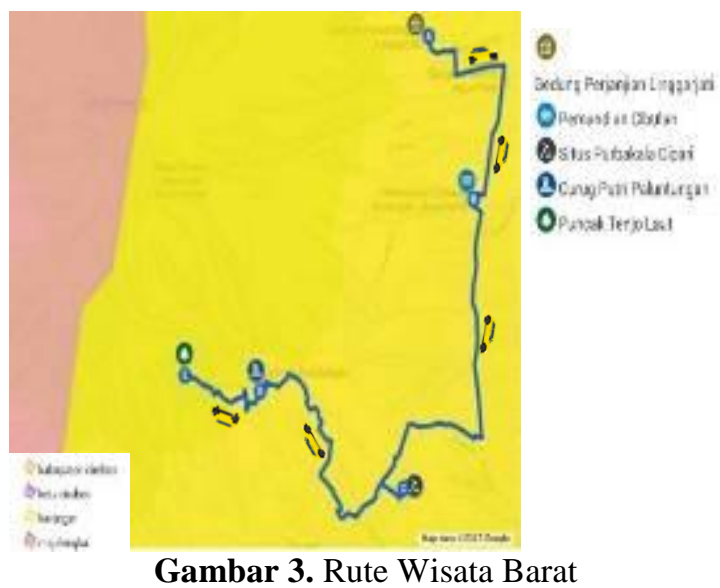

Secara keseluruhan, daya tarik yang ditawarkan dalam Rute Wisata Barat merupakan daya tarik wisata alam dan sejarah yang kemudian dikembangkan. Daya tarik yang dimaksud antara lain berupa pemandangan alam, air terjun, dan situs purbakala. Daya tarik pada kawasan ini berjarak cukup jauh dari Kota Cirebon, dengan waktu tempuh 45 menit hingga 1 jam perjalanan atau sekitar $23 \mathrm{~km}$. Sedangkan jarak antara daya tarik wisata cukup dekat, yaitu sekitar 3-5 km, karena terletak pada daerah Kuningan. Untuk menuju seluruh daya tarik di Rute Wisata Barat dari Kota Cirebon dapat melalui Jalan Cilimus-Cirebon yang memiliki fungsi jalan arteri, dengan kondisi perkerasan jalan yang sangat baik.

Sedangkan dari kondisi jalan antar masing-masing daya tarik, secara keseluruhan didominasi jalan lokal dan lingkungan. Pada jalan-jalan tersebut, kondisi jalan cukup curam dan memiliki banyak tikungan, selain itu kondisi fisik jalan juga sedikit kurang memadai, baik dari beberapa ruas jalan yang berlubang, hingga kondisi perkerasan yang masih berupa macadam dan tanah sehingga cukup rawan ketika musim penghujan.

Rute Wisata Timur terdiri dari 3 daya tarik wisata, secara berurutan adalah Batu Lawang - Telaga Nilam - Batu Luhur. Rute Wisata Timur dibuat berdasarkan data sekunder yang kemudian dikonfirmasikan lagi pada survei primer. Dapat dilihat pada gambaran peta di Gambar dibawah ini:

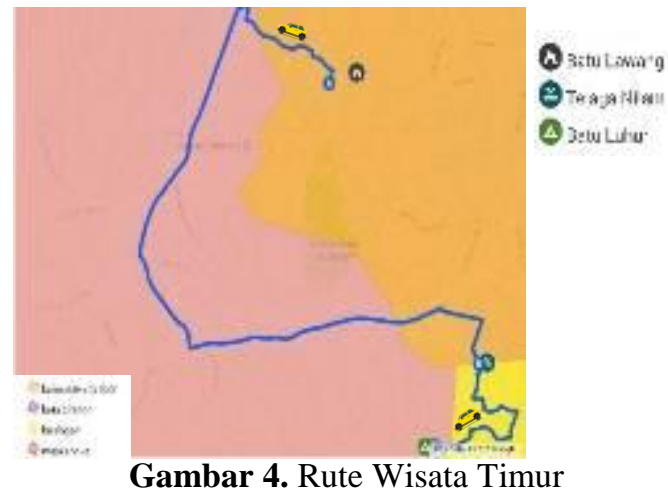

Secara keseluruhan, daya tarik yang ditawarkan dalam Rute Wisata Timur merupakan daya tarik wisata alam yang kemudian dikembangkan oleh kelompok atau komunitas masyarakat lokal. Daya tarik yang dimaksud antara lain berupa tebing batu merupakan hasil dari bekas penambangan batu yang sudah tidak pakai. Daya tarik pada kawasan ini berjarak cukup jauh dari Kota Cirebon, dengan waktu tempuh 45 menit hingga 1 jam perjalanan atau sekitar $30 \mathrm{~km}$. Sedangkan jarak antara daya tarik wisata juga cukup berjauhan sekitar $10 \mathrm{~km}$. Untuk menuju seluruh daya tarik di Rute Wisata Timur dari Kota Cirebon dapat melalui Jalan Gempol yang memiliki fungsi jalan arteri, dengan kondisi perkerasan jalan yang sangat baik. Sedangkan dari kondisi jalan antar masing-masing daya tarik, secara keseluruhan didominasi jalan lokal dan lingkungan. Pada jalan-jalan tersebut, kondisi jalan cukup curam dan memiliki banyak tikungan, selain itu kondisi fisik jalan juga sedikit kurang memadai, baik dari beberapa ruas jalan yang berlubang, hingga kondisi perkerasan yang masih berupa macadam dan tanah sehingga cukup rawan ketika musim penghujan.

Pada jalan yang dilalui untuk Rute Wisata Timur ini ketersediaan fasilitas penunjang pariwisata seperti penginapan, rumah makan, mini market, toko cinderamata atau oleh-oleh, dan lain sebagainya cukup terbatas. Fasilitas yang dapat ditemukan pada jalan-jalan tersebut antara lain warung makan dan toko kelontong. Dimana umumnya fasilitas-fasilitas tersebut melayani kebutuhan 
masyarakat sekitar, sehingga kapasitas yang dimiliki cukup terbatas walaupun pada tempat tertentu terdapat rumah makan yang memadai untuk wisata namun itu pun hanya sedikit.

Skema Pengembangan Gateway, Staging pada Rute Wisata Ciayumajakuning dibagi menjadi beberapa cluster yaitu rute wisata kota, rute wisata barat dan rute wisata timur. Terkait gateway, terdapat 3 gateway dalam pengembangan rute di Ciayumajakuning yaitu 3 gateway utama (titik masuk wisatawan dari suatu negara atau wilayah dalam rute trasportasi udara, kereta api dan jalan raya). Sedangkan untuk staging area/ hub terdapat di cluster rute wisata kota, area ini juga menjadi atraksi utama dalam kawasan wisata Kota Cirebon. Terdapat 5 Daya Tarik Wisata yang terpilih pada Wilayah Cirebon.

Main gateway atau titik masuk utama wisatawan menuju rute wisata Ciayumajakuning terdapat di pusat kota Cirebon yang berada pada Rute Wisata Kota. Hal ini terkait dengan adanya integrasi jalur kereta api yang melintasi antar provinsi yang dapat mengantarkan wisatawan dari arah barat dan timur dari Pulau Jawa. Selain itu pula terdapat jalan pantura dan jalan Tol Cipali yang memudahkan wisatawan untuk datang ke Kota Cirebon dari asal jakarta dan sekitarnya.

Staging area/hub atau area terdekat dari gateway merupakan area dimana terdapat segala fasilitas yang dibutuhkan oleh wisatawan pertama kali datang seperti akomodasi, pusat perbelanjaan, tempat makan dan minum, pelayanan pariwisata dan lainnya. Pada rute selatan staging area terletak pada pusat Kota Cirebon dimana area ini terdapat segala fasilitas dalam memenuhi kebutuhan wisatawan seperti homestay, hotel, restoran, agen wisata, pusat informasi wisata hingga pusat perbelanjaan. Selain dijadikan sebagai staging/ hub, lokasi ini juga sebagai atraksi utama dalam rute wisata Ciayumajakuning dengan adanya daya tarik di sekitarnya. Staging/ hub menjadi titik awal dilakukannya aktivitas berwisata kebeberapa daya tarik wisata terdekat. Daya tarik wisata terdekat dari staging/ hub yaitu Keraton Kasepuhan, Keraton Kacirebonan, Taman Sari Gua Sunyaragi, Cirebon Waterlan Ade Irma Suryani yang semuanya menjadi rangkaian rute wisata kota. Dapat dilihat secara konseptual di Gambar dibawah ini:

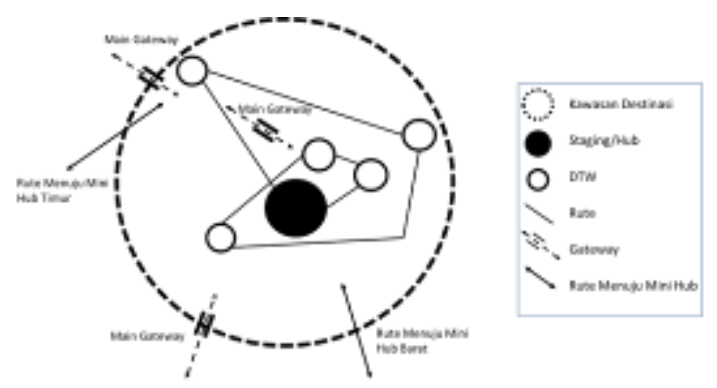

Gambar 5. Pengembangan rute wisata kota sebagai Staging Area/ Hub/ atraksi utama

Perjalanan menuju area dimana terdapat fasilitas akomodasi yang bisa digunakan wisatawan untuk menetap dan menginap kurang lebih 3 malam. Area tersebut juga menjadi titik awal wisatawan melakukan trips kebeberapa daya tarik terdekat. Wisatawan sendiri terbagi menjadi dua jenis berdasarkan tempat mereka menginap yaitu mereka yang tinggal dan menginap di base holiday trips dan mereka yang menginap di luar itu;. Terkait gateway di rute wisata barat bertipikal mini-gateway/ secondary gateway hal ini dikarenakan rute barat menjadi minihub dari rute wisata kota sebagai atraksi utama dalam rute wisata Ciayumajakuning. Rute wisata barat dimulai dengan berkunjung ke daya tarik wisata Gedung Perundingan Linggarjati-Pemandian Cibulan-Situs Purbakala Cipari-Curug Putri PaluntunganTenjo Laut. Dapat dilihat secara konseptual di Gambar dibawah ini:

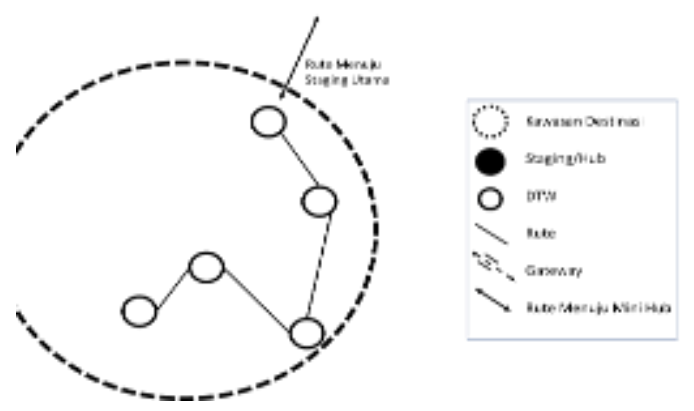

Gambar 6. Pengembangan Rute Wisata Barat sebagai Mini-Hub Barat 


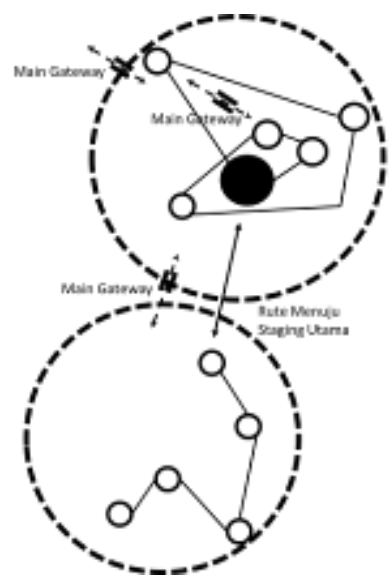

Gambar 7. Integrasi Rute Wisata Kota dan Rute Wisata Barat

Rute wisata timur memiliki persamaan dengan rute wisata barat yaitu sebagai minihub dari atrasi utama (rute wisata kota) dan bertipikal rute based Holiday Trips, bertipikal mini-gateway/secondary gateway. Hal ini dikarenakan rute wisata timurt menjadi mini-hub dari rute wisata kota sebagai atraksi utama dalam rute wisata Ciayumajakuning. Rute wisata timur dimulai dengan berkunjung ke daya tarik wisata Batu Lawang - Telaga Nilam - Batu Luhur. Dapat dilihat secara konseptual di Gambar dibawah ini:

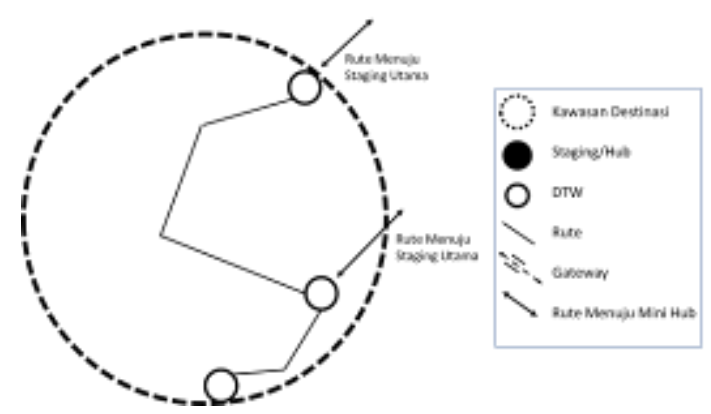

Gambar 8. Pengembangan Rute Wisata Timur sebagai Mini-Hub Timur

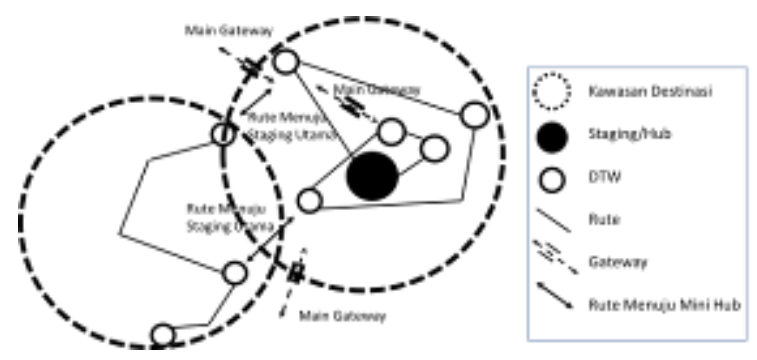

Gambar 9. Integrasi Rute Wisata Kota dan Rute Wisata Timur
Secara keseluruhan untuk mengunjungi dan menikmati daya tarik di Ciayumajakuning ini membutuhkan waktu yang berbeda-beda pada setiap rute, mulai dari satu hari, dua hari satu malam hingga tiga hari dua malam. Waktu tersebut diatur sesuai dengan rute yang diambil dan dirangkai. Dilihat dari hasil skema rute wisata Ciayumajakuning, maka dapat dibuat pula rangkaian rute wisata Ciayumajakuning dalam implementasi paket wisata harian. Untuk penjelasan lebih lanjut dapat dilihat dalam sub-bab berikut ini.

Pada bagian ini akan dijelaskan mengenai implimentasi rute wisata pada paket wisata 1 hari, dalam paket wisata ini ada tiga pilihan dimana wisatawan dapat bebas ingin memilih rute wisata yang tersedia. Berikut rute wisata untuk 1 hari :

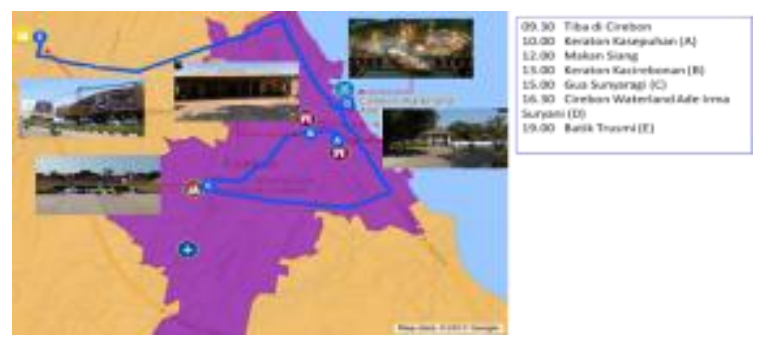

Gambar 10. Rute Wisata Kota pada Paket Wisata 1 Hari

Untuk paket wisata rute wisata kota dalam satu hari ini memiliki itinerary dengan mengunjungi 5 daya tarik wisata, perjalanan ini dimulai pada jam 09.30 karena jam mengacu dengan tibanya kereta dari jakarta ke kota cirebon, dan biasanya kegiatan tour dimulai pagi hari. Selanjutnya daya tarik yang dikunjungi pertama adalah Keraton Kasepuhan, daya tarik ini dipilih menjadi titik kegiatan pertama karena tempat ini memiliki sejarah yang sangat penting bagi Cirebon, selain itu juga tempat ini menjadi awal pusat pemerintahan Cirebon pada jaman kesultanan dan dengan mengunjungi tempat ini akan berhubungan dengan daya tarik wisata yang akan dikunjungi selanjutnya. Setelah itu wisatawan diajak untuk makan siang dengan makan makanan khas Cirebon, lalu pada titik daya tarik yang kedua dilanjut dengan mengunjungi Keraton Kacirebonan 
karena keraton ini masih mempunyai hubungan cerita sejarah dengan Keraton Kasepuhan sehingga dengan mengunjungi tempat ini dapat memperjelas cerita mengenai sejarah Cirebon.

Selanjutnya pada titik daya tarik yang ketiga mengunjungi Taman Sari Goa Sunyaragi, tempat ini masih sama dengan tempat sebelumnya yang memiliki hubungan cerita dan sejarah dengan kehidupan keraton. Setelah itu kunjungan dilanjutkan pada titik daya tarik wisata keempat yaitu Cirebon Waterland Ade Irma Suryani, sebenarnya tempat ini merupakan kolam renang namun tersedia restoran dan akomodasi dalam objek wisata ini, pada tempat ini wisatawan sembari diajak mengunjungi Cirebon Waterland tapi juga diajak untuk makan malam di restoran yang berbentuk perahu dengan melihat matahari terbenam pada pantai utara. Setelah puas makan, wisatawan menutup kegiatan tour dengan berbelanja batik khas Cirebon di Batik Trusmi yang merupakan titik daya tarik kelima.

Untuk paket wisata rute wisata barat dalam satu hari ini memiliki itinerary dengan mengunjungi 5 daya tarik wisata, perjalanan ini dimulai pada jam 07.00 karena jam mengacu dengan mengikuti jam operasional dari daya tarik yang tersedia. Selanjutnya daya tarik yang dikunjungi pertama adalah Gedung Perundingan Linggarjati, daya tarik ini dipilih menjadi titik kegiatan pertama karena jam operasional dari tempat ini dibuka dari pagi hari, selain itu tempat ini memiliki sejarah yang sangat penting bagi Indonesia maka sangat disayangkan apabila tempat ini dilewati untuk dikunjungi. Pada titik daya tarik yang kedua dilanjut dengan mengunjungi Pemandian Cibulan selain tempat yang berdekatan dengan daya tarik sebelumnya, daya tarik ini terkenal dengan ikan dewanya yang sudah sangat lama di kolam tersebut, ditempat ini wisatawan dapat berenang bersama ikan-ikan dewa atau sekedar bersantai sembari therapy ikan. Setelah lelah berenang, wisatawan diajak untuk makan siang sebelum melanjutkan perjalanan.
Selanjutnya pada titik daya tarik yang ketiga mengunjungi Situs Purbakala Cipari, tempat ini berisikan bebatuan yang digunakan pada jaman batu, wisatawan dapat melihat berbagai batu yang digunakan pada jaman dahulu seperti batu menhir, batu gelang, dan alat-alat dari batu. Setelah itu kunjungan dilanjutkan pada titik daya tarik wisata keempat yaitu Curug Putri Paluntungan, sebenarnya tempat ini merupakan daya tarik pilihan dimana sebelumnya wisatawan sudah diajak main air di Pemandian Cibulan, sehingga pada tempat ini menjadi pilihan bagi wisatawan akan dikunjungi atau tidak. Selanjutnya pada titik daya tarik wisata kelima yaitu Tenjo Laut, ditempat ini wisatawan dapat melihat pemandangan kota Kuningan dari atas, tidak hanya itu wisatawan juga dapat mengikuti kegiatan outbound, offroad yang tersedia di daya tarik ini. Rute dan jadwal dapat dilihat pada gambar dibawah ini :

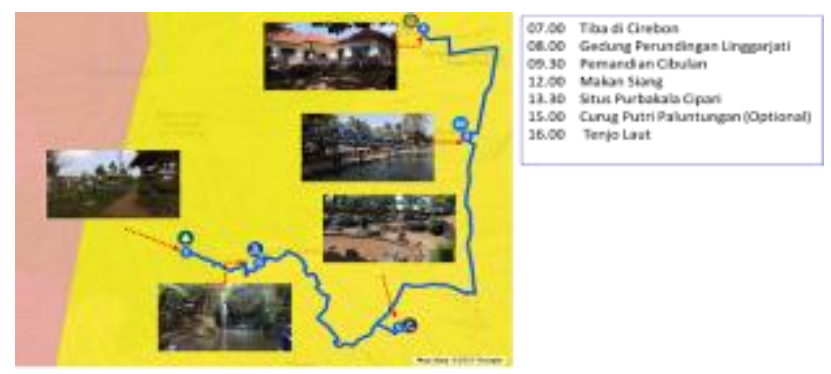

Gambar 11. Rute Wisata Barat pada Paket Wisata 1 Hari

Untuk paket wisata rute wisata timur dalam satu hari ini memiliki itinerary dengan mengunjungi 3 daya tarik wisata disebabkan lokasi antara daya tarik yang cukup berjauhan, perjalanan ini dimulai pada jam 09.30 karena jam mengacu dengan tibanya kereta dari jakarta ke kota cirebon, dan biasanya kegiatan tour dimulai pagi hari. Selanjutnya daya tarik yang dikunjungi pertama adalah Batu Luhur, daya tarik ini dipilih menjadi titik kegiatan pertama karena tempat ini memiliki kegiatan seperti tracking dan offroad dan wilayahnya cukup luas sehingga dibutuhkan waktu yang cukup leluasa.

Setelah itu wisatawan diajak untuk makan siang di rumah makan ikan bakar yang banyak tersedia dalam perjalanan menuju daya tarik wisata selanjutnya, lalu 
pada titik daya tarik yang kedua dilanjut dengan mengunjungi Telaga Nilam, tempat ini merupakan salah satu spot terbaik snorkeling pada air tawar, karena air disini murni dari mata air gunung ceremai yang sangat menyegarkan dan bersih sehingga sangat disayangkan apabila tidak mencoba berenang. Selanjutnya pada titik daya tarik yang ketiga mengunjungi Batu Lawang, tempat ini merupakan bekas tempat pertambangan batu yang sudah tidak digunakan lagi, dengan keunikan dan keindahan yang terbuat secara tidak sengaja kelompok atau komunitas setempat mengemas tempat ini menjadi tempat wisata. Selain itu ditempat ini juga wisatawan dapat mencoba panjat tebing atau sekedar melihat pemandangan sebelah timur dari gunung ceremai. Rute dan jadwal dapat dilihat pada gambar dibawah ini :

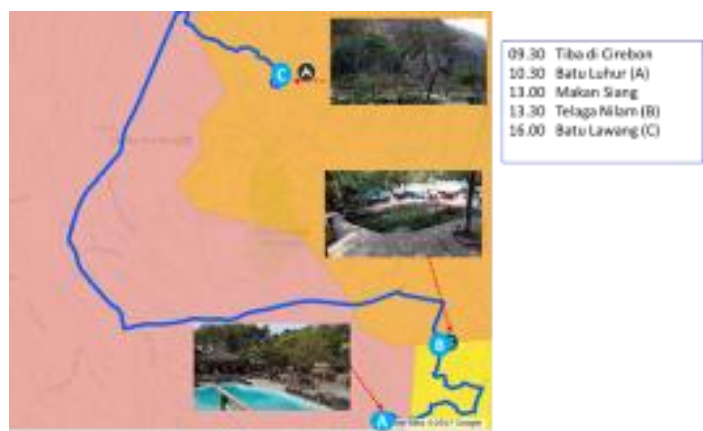

Gambar 12. Rute Wisata Timur pada Paket Wisata 1 Hari

Pada dasarnya paket wisata dua hari satu malam ini terdiri dari antara penggabungan rute wisata kota-rute wisata barat dan rute wisata kota-rute wisata timur. Untuk itinerary yang tersedia juga masih sama dengan sebelumnya, hanya saja pembedanya adalah wisatawan menginap di daerah cirebon yang merupakan daerah staging pada rute wisata Ciayumajakuning ini, dan dalam paket wisata 2 hari 1 malam ini dibuat menjadi dua opsi antara rute wisata kota-rute wisata barat dan rute wisata kota-rute wisata timur agar wisatawan dapat memilih untuk lebih menyukai paket wisata yang seperti apa. Paket wisata tersebut dapat dilihat pada gambar dibawah ini:

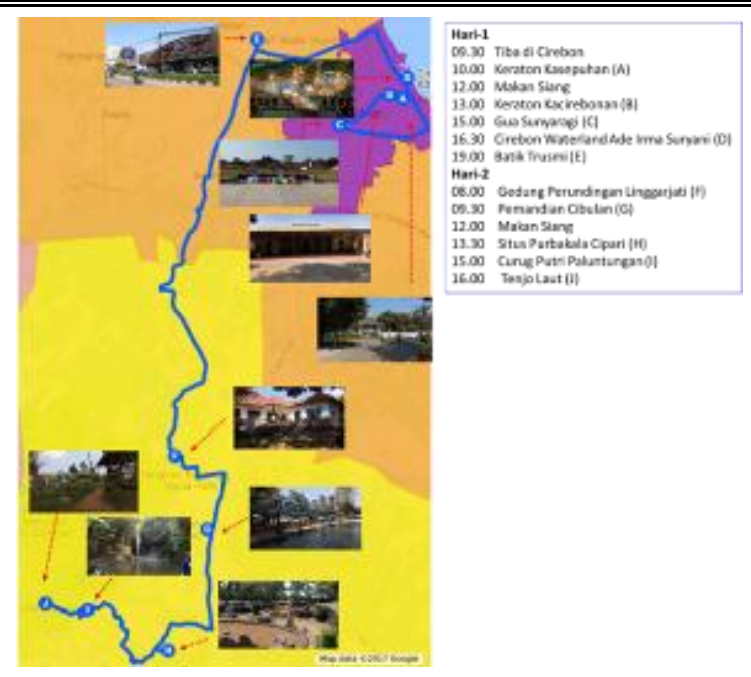

Gambar 13. Rute Wisata Kota dan Rute Wisata Barat pada Paket Wisata 2 Hari 1 malam

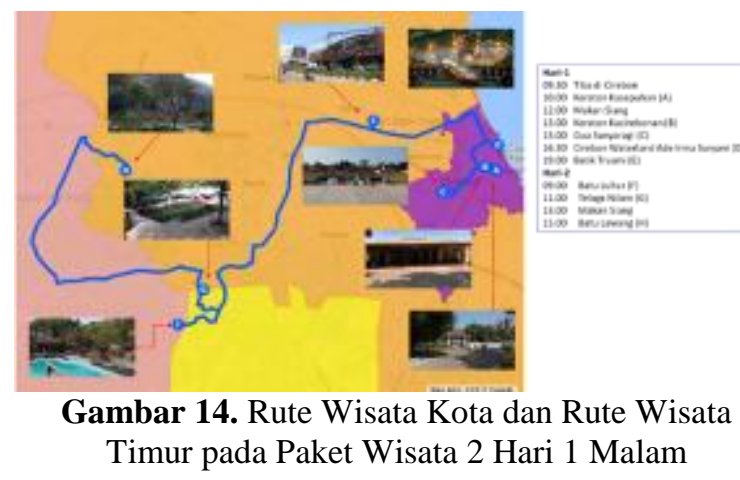

Pada paket wisata tiga hari dua malam ini sebenarnya itinerary masih sama dengan itinerary rute wisata satu hari, hanya saja pada tahap ini dilakukan penggabungan tiga rute wisata Ciayumajakuning. pada hari pertama kegiatan tour dilakukan dengan rute wisata kota, selanjutnya hari kedua kegiatan tour dilakukan dengan rute wisata barat, dan pada hari terakhir kegiatan tour dilakukan dengan rute wisata timur. Pada kegiatan tour ini start setiap harinya dimulai dari kota Cirebon karena wisatawan menginap di Kota Cirebon yang merupakan staging area pada rute wisata Ciayumajakuning ini. Paket wisata tersebut dapat dilihat pada gambar dibawah ini 


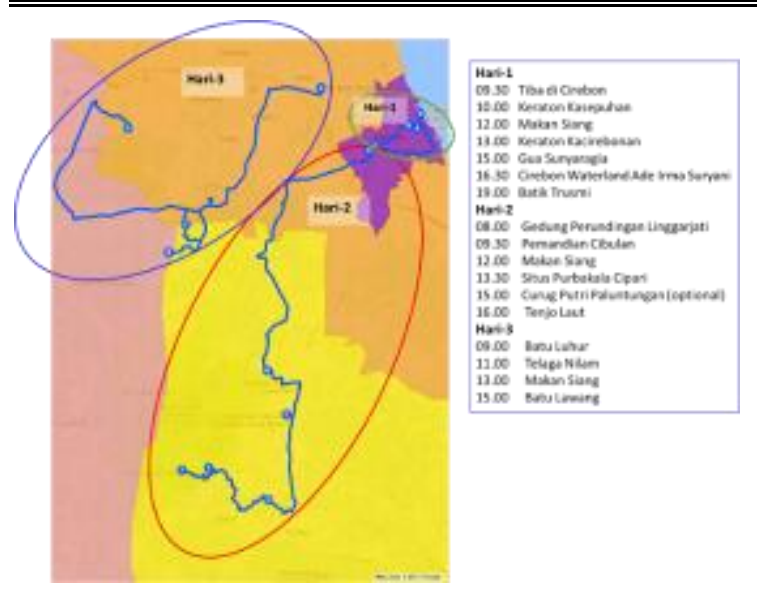

Gambar 15. Rute Wisata Ciayumajakuning dalam Paket Wisata 3 Hari 2 malam

\section{III.SIMPULAN}

Berdasarkan pembahasan pada bab-bab sebelumnya, sesuai dengan tujuan dan sasaran penelitian maka kesimpulan yang didapat dari hasil kajian ini adalah sebagai berikut:

1. Potensi wisata yang dapat dikembangkan di Kawasan Ciayumajakuning berjenis wisata alam, sejarah, dan budaya. Saat ini kawasan wisata di Ciayumajakuning semakin berkembang dengan meningkatnya jumlah kunjungan wisatawawan setiap tahunnya, terutama sejak beroperasinya Jalan Tol Cipali.

2. Kondisi daya tarik wisata di Ciayumajakuning saat ini mayoritas masih minim fasilitas penunjang pariwisata, seperti amenitas dan aksesibilitas kawasan yang menjadi faktor terpenting dalam menarik wisatawan.

3. Aksesibilitas daya tarik wisata di Ciayumajakuning secara eksternal sudah sangat baik dengan adanya jalur kereta api dan jalan tol, ditambah lagi dengan adanya Bandara Kertajati di kemudian hari yang dapat menjadi gerbang masuk wisatawan mancanegara.

4. Rute Wisata Ciayumajakuning dibagi menjadi 3, yaitu:
a. Rute Wisata Kota (Keraton
Kasepuhan-Keraton Kacirebonan-
Taman Sari Gua Suyaragi-Cirebon Waterland Ade Irma Suryani-Batik Trusmi)

b. Rute Wisata Barat (Gedung Perundingan Linggarjati-Pemandian Cibulan-Situs Purbakala CipariCurug Putri Paluntungan - Tenjo Laut)

c. Rute Wisata Timur (Batu LawangTelaga Nilam-Batu Luhur).

Infrastruktur yang dibutuhkan untuk mendukung aksesibilitas dan pengembangan rute wisata Ciayumajakuning antara lain adalah perbaikan jalan berlubang; pelebaran jalan yang sempit; serta pengaspalan jalan tanah.

Rute perjalanan wisata pada hakekatnya direncanakan untuk digunakan wisatawan bergerak dari satu objek wisata ke objek wisata lainnya, dengan pengembangan yang ditekankan pada pengembangan pola rute lintasan persinggahan. Sedangkan distribusi pengembangan sarana dan prasarana kepariwisataan dimaksudkan untuk melengkapi rute perjalanan yang telah ditentukan tersebut agar menjadi suatu rute perjalanan yang menarik yang dilengkapi oleh kemudahan-kemudahan perjalanan bagi wisatawan yang berkunjung.

Pengembangan sarana dan prasarana kepariwisataan untuk masing-masing objek wisata menggambarkan jenis-jenis sarana maupun prasarana yang dibutuhkan oleh masing-masing objek wisata sesuai dengan potensi yang dimilikinya. Pada dasarnya apa yang telah dicapai pada studi ini adalah memberikan suatu arah terhadap pengembangan kepariwisataan di Ciayumajakuning. Dengan demikian, pengarahan dalam studi ini dapat dijadikan masukan bagi pemerintah daerah untuk mengarahkan industri pariwisata sesuai dengan kondisi dan potensi yang ada.

\section{REFERENSI}

\section{Buku}

Cook R, Yale R, Marqua J. (2014). Tourism: The Business Hospitality and Travel (Fifth Edition). New Jersey: Pearson Prentice Hall.

Croes, R., \& Rivera, M. (2015). Poverty Alleviation Through Tourism 
Development: A Comprehensive And Integrated Approach. Crc Press. New Jersey: Routledge.

Faizi Zahari, (2012), Mengapa Perencanaan Pariwisata Itu Penting. Bandung: The Planners Eportfolio.

IATA, (2014). The Business Environment Of Travel And Tourism Industry. Annual Reports.

Inskeep Edward. (2001). Tourism Planning An Integrated and Sustainable. Development Approach. New York: Van Nostrand Reinhold.

BP2D Jawa Barat. (2016). Kajian Sistem Angkutan Umum Cepat Massal Di Kawasan Metropolitan Jawa Barat. (2016). Bandung: BP2D Jawa Barat.

Kotler, Philip. \& Gary Armstrong. (2014). Principle Of Marketing, 15th Edition. New Jersey: Pearson Prentice Hall.

Pearce, Douglas (2012). The Framework For Tourism Research. London: MPG Books Ltd.

M.A. Camilleri. (2017). Travel Marketing, Tourism Economics And The Airline Product, Tourism, Hospitality \& Event Management. New York: Springer International Publishing.

Meyer, Dorothea. (2004). Tourism Routes And Gateways: Key Issues For The Development Of Tourism Routes And Gateways And Their Potential For ProPoor Tourism. London: Overseas Development Institute.

Mulyadin (2008): Kajian Penentuan Alternatif Rute Perjalanan Pariwisata Di KPP Kalianda Kabupaten Lampung Selatan. Tesis Institut Teknologi Bandung.

Philips, Rhonda \& Roberts, Sherma. (2013). Tourism, Planning and Community Development. New York: Routledge.

Sugiyono. (2015). Metode Penelitian Kuantitatif, Kualitatif dan $R \& D$. Bandung: Alfabeta.

Tim BP3IPTEK. (2016). Kajian Sistem Angkutan Umum Cepat Massal Di Kawasan Metropolitan Jawa Barat. Bandung: Bp3iptek Provinsi Jawa Barat.

Tim PT Optima Solusi Indonesia. (2015). Laporan Akhir Dampak Tol Cipali Terhadap Ekonomi Di Cirebon. Cirebon: Bank Indonesia Kpwdn Cirebon
Tim PT Optima Solusi Indonesia. (2016). Laporan Akhir Dampak Kedatangan Wisatawan Terhadap Aktivitas Konsumsi Kuliner, Barang Kerajinan Dan Perhotelan Di Cirebon. Cirebon: Bank Indonesia Kantor Wilayah Cirebon

\section{Jurnal}

Briedenhann, J., \& Wickens, E. (2004). Tourism Routes As A Tool For The Economic Development Of Rural Areas-Vibrant Hope Or Impossible Dream? Tourism Management. Tourism Management. 25 (1), 71-78.

Dredge, D. (2009). Destination Place Planning And Design. Annals of Tourism Research Journals, Vol 26, 772-791.

Flognfeldt Jr, T. (2002). Impacts From The Short Time Visitors To Local Communities In The Mountain Areas Of Southern Norway. The International Journal of Tourism Research, (20-35).

Gautama, I. G. A. G. O., (2011): Evaluasi Perkembangan Wisata Bahari Di Pantai. Sanur. Tesis. Denpasar: Program Pascasarjana Universitas Udayana.

Lourens, M. (2008). The Underpinnings For Successful Route Tourism Development In South Africa. Doctoral Dissertation South Africa of University.

Nasimussabah. (2016): Pola Pergerakan Wisatawan Malaysia Di Wilayah Metropolitan Bandung Raya. Tesis Institut Teknologi Bandung.

Silvia. (2016): Identifikasi Pola Pergerakan Wisatawan Di Kawasan Wisata Lembah Harau. Tesis Institut Teknologi Bandung.

Symon, Nkonoki. (2012). Challenges Of Tour Operators Case: Dar-Es-Salaam, Tanzania. Tesis University Of Applied Sciences Haaga-Helia.

Widyasmi, Kartika. (2012): Strategi Pengelolaan Pariwisata Bahari Di Kecamatan Bayah Kabupaten Lebak. Skripsi Universitas Agung Tirtayasa.

\section{Peraturan}

Peraturan Daerah No 22 Tahun 2010 Tentang RTRWP Jawa Barat 2009-2029

Peraturan Daerah Provinsi Jawa Barat Nomor 15 Tahun 2015 Tentang Rencana Induk 
Pembangunan Kepariwisataan Provinsi Jawa Barat Tahun 2015-2025

Peraturan Pemerintah Republik Indonesia Nomor 50 Tahun 2011 Tentang Rencana Induk Pembangunan Kepariwisataan Nasional Tahun 2010 - 2025.

Rencana Pembangunan Jangka Menengah Daerah (RPJMD) Kota Cirebon 20132018.

Undang-Undang Republik Indonesia No. 10 Tahun $2009 . \quad$ Tentang. Kepariwisataan:Jakarta.

World Tourism Organization (UNWTO). (2014):

Unwto Tourism Highlights, 2014.

Edition 